\title{
TWO NEW SPECIES OF THE GENUS GOVENIA (ORCHIDACEAE, VANDOIDEAE) FROM COLOMBIA
}

\author{
Dariusz L. SzlachetKo \& Marta KolanowsKa ${ }^{1}$
}

\begin{abstract}
Two new species of Govenia Lindl. from Colombia are described and illustrated: G. plowmanii and G. renilabia. Their taxonomic affinities are briefly discussed, and information on the ecology and distribution of the new entities is provided. Both new species are placed within a key for identification of Colombian Govenia species.
\end{abstract}

Key words: Colombia, Govenia, new species, Orchidaceae, taxonomy.

Dariusz L. Szlachetko \& Marta Kolanowska, Department of Plant Taxonomy and Nature Conservation, University of Gdańsk, Wita Stwosza 59,80-308 Gdańsk, Poland; e-mail: martakolanowska@wp.pl

\section{INTRODUCTION}

The genus Govenia was proposed by Lindley (1831) based on the morphology of Maxillaria superba La Llave \& Lex. From Maxillaria he separated species characterized by plicate leaves gradually narrowed to a petiolate base, recurved in the natural position, an undivided lip much shorter than tepals, a short and massive, usually strongly arcuate gynostemium, an incumbent anther and amorphous caudiculae.

The taxonomic position of the genus is still discussed, as the results of molecular studies are inconsistent (Cameron et al. 1999; Freudenstein et al. 2004) and do not correspond to morphology-based classification systems (Dressler 1981, 1993; Szlachetko 1995). Three main groups of species are recognized within the genus: Purpusii, Capitata and Superba (GarcíaCruz \& Sosa 2005). They are grouped based on the presence of a rhizome versus pseudobulbs, the number of leaves and the inflorescence arrangement. The generic separateness of Govenia is not in doubt, but the problem concerns delineation of infrageneric taxa, a problem first noted by Lindley (1845). Species delimitation is difficult mainly due to an insufficient number

\footnotetext{
1 Corresponding author
}

of collections of Govenia species represented in herbaria.

Nowadays the genus embraces $c a 28$ species distributed from Argentina to Mexico (Greenwood 1981; García-Cruz \& Sosa 2005); 17 are found in Mesoamerica, seven in South America, one is restricted to the West Indies and another one to Florida (Dressler 1965; Greenwood 1981). The altitudinal range of Govenia is limited to premontane and montane areas, between 1200 and $2800 \mathrm{~m}$ a.s.l. Plants are often found in shady forests growing on organic soils (García-Cruz \& Sosa 2005).

Ortiz and Uribe (2007) compiled a list of only seven Govenia species occurring in Colombia, but our recent revision of the orchid material stored in Colombian herbaria resulted in the discovery of two taxa which are described here as new.

\section{DESCRIPTIONS OF THE NEW SPECIES}

Govenia plowmanii Szlach. \& Kolan., sp. nov.

Fig. 1

Plants similar to Govenia fasciata Lindl. but with lip concave in the center, constricted in the apical third, with the basal part obreniform and the apical part much smaller and transversely elliptic. 
Holotype: COLOMBIA. Huila. San Agustin, road to El Estrecho. Secondary forest along road, 16 Aug. 1974, Plowman \& E.W. Davis 4159 (COL).

Plants bifoliate. Leaves petiolate; petiole to $35 \mathrm{~cm}$ long, narrow; blade to $33 \mathrm{~cm}$ long and 8-9 cm wide, oblong-elliptic, acute. Inflorescence erect; peduncle $66 \mathrm{~cm}$ long; rachis $10 \mathrm{~cm}$ long, subdensely many-flowered. Flowers rather small. Floral bracts $10 \mathrm{~mm}$ long, lanceolate, acuminate. Pedicel and ovary $22 \mathrm{~mm}$ long. Dorsal sepal $13 \mathrm{~mm}$ long, $3 \mathrm{~mm}$ wide, oblong to linear-lanceolate, obtuse, 5-nerved. Petals $12 \mathrm{~mm}$ long, $6 \mathrm{~mm}$ wide, semi-elliptic, strongly oblique, acute to shortly acuminate, outer margins somewhat undulate, 5-nerved. Lateral sepals $9 \mathrm{~mm}$ long, $5 \mathrm{~mm}$ wide, ligulate with \pm lanceolate, acute apex, strongly falcate, 5-nerved. Lip shortly clawed; lamina $5 \mathrm{~mm}$ long and wide, 5-nerved, lateral nerves branching, concave in center, constricted in apical third, with

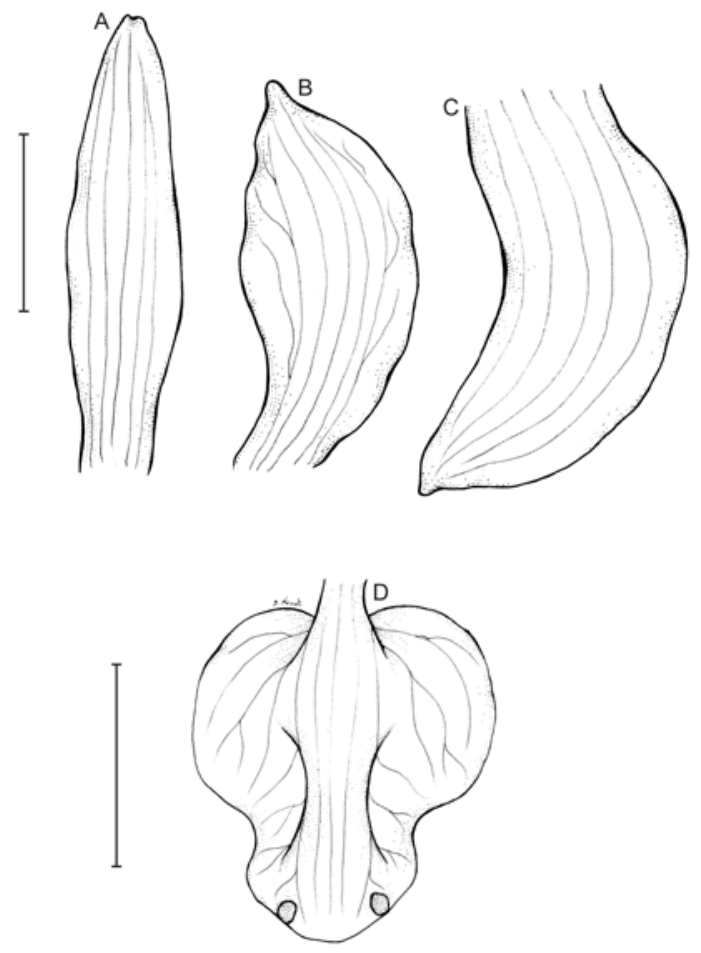

Fig. 1. Govenia plowmanii Szlach. \& Kolan.- dissected perianth. A - dorsal sepal; B - petal; C - lateral sepal; D - lip. Scale bar $A-C=5 \mathrm{~mm}, \mathrm{D}=3 \mathrm{~mm}$. Drawn by $\mathrm{S}$. Nowak from holotype. basal part obreniform and apical part much smaller, transversely elliptic, apex obtuse, with two prominent spots. Gynostemium $7 \mathrm{~mm}$ long.

ETymology. Dedicated to Timothy Plowman (1944-1989), the co-collector of the original material.

ECOLOGY. Secondary forest. Alt. 1417 m. Flowering in August and June.

Distribution. Known so far from the departments of Huila and Santander, Colombia (see Fig. 3).

Notes. This species is easily distinguishable from all other Govenia species by its peculiar lip form.

Govenia renilabia Szlach. \& Kolan., sp. nov.

Fig. 2

Plants similar to Govenia tingens Poepp. \& Endl. but lip obreniform, entire, convex in center, and dorsal sepal long-clawed.

Holotype: COLOMBIA, Magdalena, Sierra Nevada de Santa Marta. Camino entre Quebrada Cebolleta y San Pedro. Extremo oriental de la Cuchilla Yerbabuena. Bosque nublado, 2400-2700 m, 4 Aug. 1972, E. Forero \& Kirkbride $663(\mathrm{COL})$.

Plants bifoliate. Leaves petiolate; petiole to $25 \mathrm{~cm}$ long, narrow; blade to $40 \mathrm{~cm}$ long and $12 \mathrm{~cm}$ wide, oblong-elliptic, acute. Inflorescence erect; peduncle $55 \mathrm{~cm}$ long; rachis $12 \mathrm{~cm}$ long, subdensely several-flowered. Flowers rather small. Floral bracts $15 \mathrm{~mm}$ long, lanceolate, acuminate. Pedicel and ovary $17 \mathrm{~mm}$ long. Dorsal sepal $16 \mathrm{~mm}$ long, $6 \mathrm{~mm}$ wide, oblong-lanceolate above long, linear claw, subobtuse, 5-nerved. Petals $10 \mathrm{~mm}$ long, $5 \mathrm{~mm}$ wide, semi-elliptic, strongly oblique, acute, 4-nerved. Lateral sepals $10 \mathrm{~mm}$ long, $6 \mathrm{~mm}$ wide, semi-elliptic-obovate, strongly oblique, acute, 5-nerved. Lip shortly clawed; lamina $6 \mathrm{~mm}$ long and wide, obreniform, obtuse at apex, subcordate at base, 7-nerved, lateral nerves branching, convex. Gynostemium $7 \mathrm{~mm}$ long.

ETymology. The specific epithet is an allusion to the lip form (Latin ren - kidney, labia - lip). 

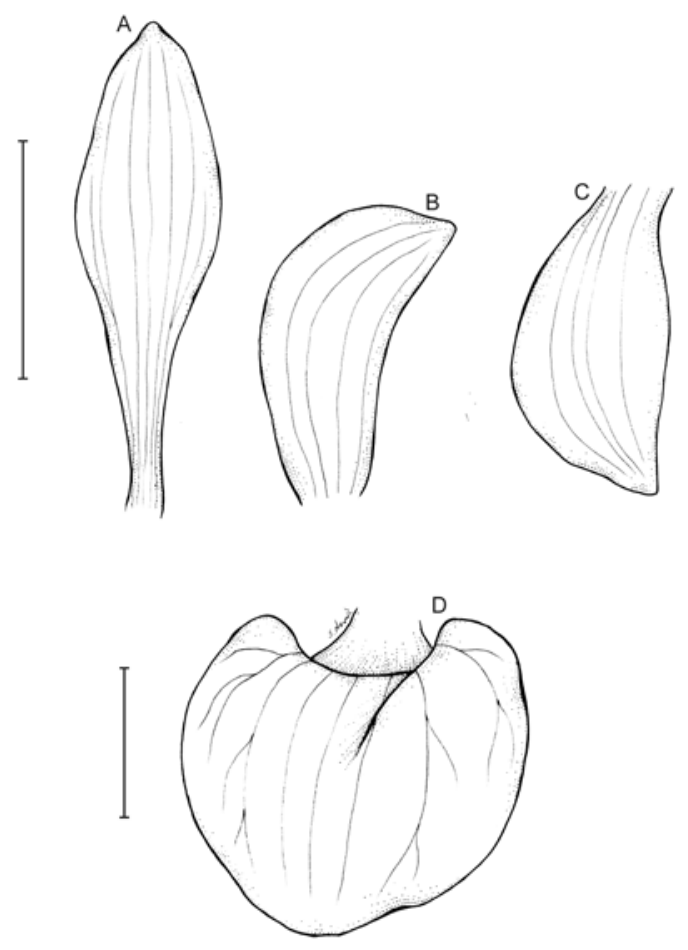

Fig. 2. Govenia renilabia Szlach. \& Kolan. - dissected perianth. A - dorsal sepal; B - petal; C - lateral sepal; D - lip. Scale bar $\mathrm{A}-\mathrm{C}=8 \mathrm{~mm}, \mathrm{D}=3 \mathrm{~mm}$. Drawn by $\mathrm{S}$. Nowak from holotype.

Ecology. Cloud forest. Alt. 2400-2700 m. Flowering in August.

Distribution. Known from the Colombian department of Magdalena (Fig. 3).

Notes. This species differs from $G$. tingens Poepp. \& Endl. by having a clawed dorsal sepal which is much longer than the lateral sepals and petals, and by its obreniform lip.

\section{Key to THE COLOMbian SPECIES OF Govenia}

1. Inflorescence shorter than leaves $\ldots \ldots \ldots \ldots 2$

1. Inflorescence subequal or longer than leaves ... 3

2. Lip up to $12 \times 8 \mathrm{~mm}$, ovate to ovate-elliptic when spread out, rounded to obtuse at apex ......... G. utriculata (Sw.) Lindl.

2. Lip $10 \times 10 \mathrm{~mm}$, oblong-subquadrate, slightly contracted near middle, apex subtruncate, minutely apiculate ... G. liliacea (La Llave \& Lex.) Lindl.

3. Rachis rather short, up to $10-15 \mathrm{~cm}$ long ..... 4

3. Rachis up to $35 \mathrm{~cm}$ long and more ........ 7

4. Floral bracts almost as long as ovaries ..... 5

4. Floral bracts about twice shorter than ovaries . . 6

5. Lip oblong . . . . . . . fasciata Lindl.

5. Lip obreniform ... G. renilabia Szlach. \& Kolan.

6. Lip triangular-ovate or ovate-oblong when expanded ........ G. tingens Poepp. \& Endl.

6. Lip constricted in apical third, basal part obreniform, apical part transversely elliptic ........ .......... G. plowmanii Szlach. \& Kolan.

7. Rostellum small, oblate

G. latifolia (Kunth) Garay \& G.A. Romero

7. Rostellum medium-sized, not flattened ...... 8

8. Leaves broadly elliptic to obovate-elliptic, lip broadly ovate to ovate-elliptic ............. ....... G. superba (La Llave \& Lex.) Lindl.

8. Leaves obovate-oblong, lip oblong .......... G. platyglossa Schltr.

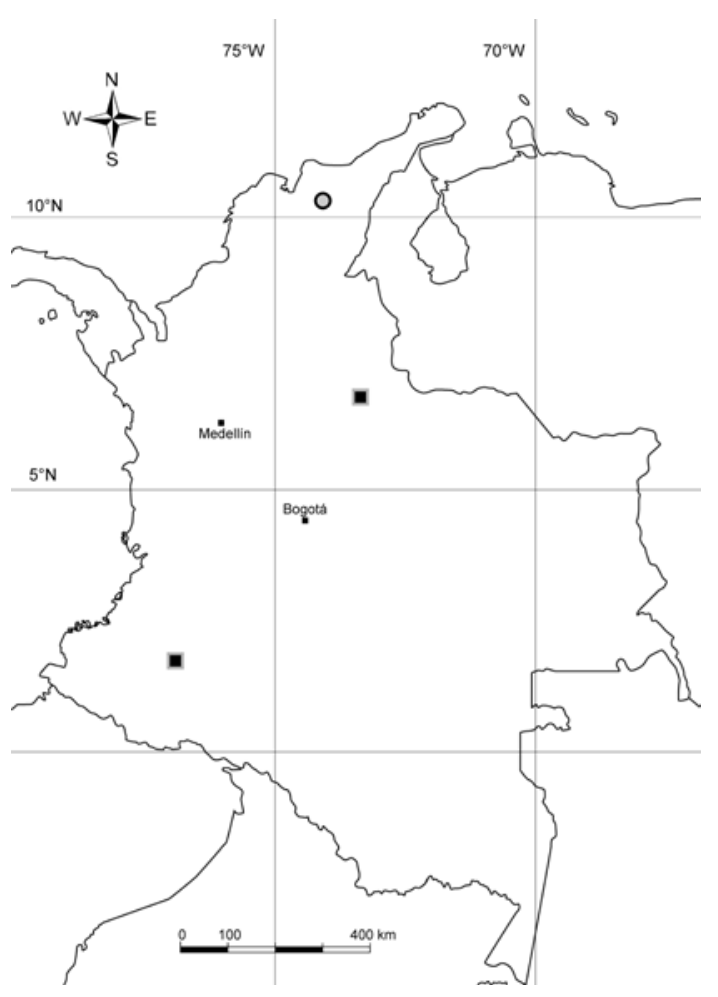

Fig. 3. Distribution of Govenia plowmanii Szlach. \& Kolan. (square) and G. renilabia Szlach. \& Kolan. (circle) in Colombia. 
ACKNOwledgements. The Curators and staff of the cited herbaria are thanked for their kind hospitality and assistance during visits and for making specimens available on loan. We are grateful to the anonymous reviewers for valuable remarks on the manuscript and to Sławomir Nowak for preparing the illustrations. The research described here was supported by the Polish Ministry of Science and Higher Education (grant no. 8124/B/PO1/2011/40).

\section{REFERENCES}

Cameron M. K., Chase W. M., Whitten W. M., Kores P. J., Jarrell D. C., Albert V. C., Yukawa T., Hills H. G. \& Goldman D. H. 1999. A phylogenetic analysis of the Orchidaceae: Evidence from rbcL nucleotide sequences. Amer. J. Bot. 86: 208-224.

Dressler R. L. 1965. Notes on the genus Govenia in Mexico (Orchidaceae). Brittonia 17: 266-277.

DRESSLER R. L. 1981. The orchids: natural history and clas- sifications. Harvard University Press, Cambridge, Massachusetts.

Dressler R. L. 1993. Phylogeny and classification of the orchid family. Dioscorides Press, Portland.

Freudenstein V. J., van den Berg C., Goldman H. D., Kores J. P., Molvray M. \& Chase W. M. 2004. An expanded plastid DNA phylogeny of Orchidaceae and analysis of jackknife branch support strategy. Amer. J. Bot. 91: 149-157.

García-Cruz J. \& Sosa V. 2005. Phylogenetic relationships and character evolution in Govenia (Orchidaceae). Canad. J. Bot. 83: 1329-1339.

Greenwood E. W. 1981 Govenia in Mexico: an introductory note. Orquidea (Mexico City) 8: 114-120.

Lindley J 1831. Govenia. Bot. Cab. 18: t. 1709.

Lindley J. 1845. Govenia fasciata. Bot. Reg. 31: t. 67.

Ortiz V. P. \& Uribe V. C. 2007. Galería de Orquídeas de Colombia (CD edition). Asociación Bogotana de Orquideología, Bogotá.

SzlachetKo D. L. 1995. Systema orchidalium. Fragm. Florist. Geobot., Suppl. 3: 1-152. 